\title{
Of Principle and Principal: Value Plurality in the Market of Impact Investing
}

\author{
Emily Barman
}

\begin{abstract}
Impact investing-investment with the intentional expectation of social or environmental impact alongside financial return-constitutes one of a growing array of "concerned markets" where economic exchange is employed as a means to pursue financial and social or environmental value. Drawing from the pragmatist turn in valuation studies, this article attends to the valuation work that took place in the formation of this new market, examining how market proponents as evaluators recognized, defined, and negotiated the presence of value complexity in impact investing. I frame the market of impact investing as a case of market design complete with experiments, one in which advocates produced a valuation infrastructure so as to address investors' difficulty in ascertaining the social and environmental value-as a distinct regime of value from financial value-of an investment. These experimenters extended judgment devices from mainstream finance to construct calculative tools in this setting that permitted the social or environmental value of investments to be brought into being and to be made calculable for investors without being assigned a financial value. The study contributes to literature that theorizes the conditions underlying evaluators' mediation of the multiple registers of value at work in the making of markets.
\end{abstract}

Key words: economic sociology; valuation; value plurality; intermediaries; concerned markets; impact investing

Impact investing-financial investment in companies with business models that produce financial value and generate social and environmental value-constitutes one of a proliferating assortment of markets intended to address social inequities and environmental challenges. These new "concerned" (Geiger et al. 2014) or "civilizing" markets (Callon 2009), include ethical consumption (O’Rourke 2005),

Emily Barman, Department of Sociology, Boston University, eabarman@bu.edu

(C) 2015 Emily Barman

LiU Electronic Press, DOI 10.3384/VS.2001-5592.15319

http://valuationstudies.liu.se 
clean technology (Doganova and Karnøe 2015), and carbon trading (MacKenzie 2009). Drawing from the pragmatist turn in valuation studies (Dewey 1939; Muniesa 2012), this article attends to the valuation work that took place in the early and formative history of this new market. If financial valuation is about "actively and practically considering value precisely for the purpose of business," (McFall 2014, 155), what happens when new regimes of value, based on social and environmental benefit, are central to the envisioning of a new financial market alongside the traditional pursuit of economic value?

The pragmatist approach to value provides a particular framework for the empirical investigation of this question. To begin, it argues that the question of value in markets does not result from an aggregation of members' exogenous and fixed preferences. Instead, value is understood as a social construction. By this assertion, this scholarship does not assume that value results from actors' subjective preferences, as shaped by collective norms and networks. Value instead is generated out of the valuation practices, conventions, and devices present in the situation of study. This emerging literature on valuation focuses on the socio-technical arrangements present in a setting that qualify goods, create calculative agents, and facilitate valuation (Callon 1998; Muniesa et al. 2007; Stark 2011; Lamont 2012; Helgesson and Muniesa 2013). Recent studies have extended the pragmatist approach beyond the study of economic value, by examining the plurality of values present in markets (Helgesson and Kjellberg 2013), often with a focus on new concerned markets where economic exchange is envisioned as a means to achieve a specific social, political, or environmental goal (Callon 2009; Geiger et al. 2014; Antal et al. 2015).

Drawing on an in-depth qualitative case study, I investigate how the presence of multiple regimes of value, including economic, social, and environmental value, was recognized, defined, and negotiated in the early years of the market of impact investing. Impact investing is a relatively new type of finance market, first emerging in 2007, and is characterized by investors providing capital to companies and funds with the intention to generate "social and environmental impact alongside financial return" (GIIN 2015). Heralded by powerful proponents as superior to the efforts of civil society or the state, impact investing consists of actors' investment of financial capital in companies located in developed and developing countries that are "double bottom line" in nature, with the intentional expectation of social or environmental impact through firms' business models, including the generation of entrepreneurial and employment opportunities, the provision of quality employment, and the sale of socially beneficial goods and services to underserved populations, alongside the production of economic return to investors (Bugg-Levine and Emerson 2011). 
In order to grow this new market, proponents, in the role of evaluators, constructed a number of calculative tools, including a reporting standard and a rating system for firms, through which the social or environmental value of firms was to be assessed, as juxtaposed to and distinct from the calculative tools that assigned their financial value. The construction of this socio-technical arrangement can be viewed as a case of market design replete with experiments (Muniesa and Callon 2007; Callon 2009), as shaped by the prioritization of investors as users of these market devices, and by the transposition of the calculative tools of finance to this new setting. Market proponents sought to produce a valuation infrastructure to respond to investors' expressed uncertainty of the social or environmental impact-as a distinct regime of value-of impact investing. These new market devices allowed the social and environmental value of investments not only to be made calculable for market members but also to be brought into being as a source of value in this market (Callon and Muniesa 2005; Callon 2008; Muniesa 2012). In other words, the success of proponents' efforts to frame and structure impact investing as a financial market was contingent upon the distinct economization and non-economization of investors' social and environmental value.

The study of valuation work in the market of impact investment matters for several reasons. In its empirical attention to the construction of the setting's calculative tools, the essay contributes to efforts in valuation studies to theorize the conditions and configuration of valuation in markets as characterized by manifold and plural modes of value beyond economic value, including social, cultural, and political value (Helgesson and Muniesa 2013; Trompette 2013). The case also provides insights into the question of valuation in an expanding assortment of concerned markets where value complexity is overt in that economic exchange is viewed as a means to achieve both economic and non-economic sources of value (Callon 2009; Geiger et al. 2014; Antal et al. 2015). The study of valuation in this new market also matters for more practical reasons. The valuation infrastructure in impact investing likely has "performative" effects (MacKenzie and Millo 2003); it structures investors' evaluation of some investments as "good" choices, thus shaping these actors' decision to direct dollars to some companies rather than others, with consequences for why some social and environmental challenges get recognized as "worthy" while others get overlooked.

In the following, I begin with an overview of the pragmatist approach to the study of value and valuation. I then provide an overview of the case of the market of impact investing, before presenting my data and method of analysis. The next section, The Pragmatist Study of Value, delineates the valuation work of market proponents in constructing the market of impact investing, including 


\section{Valuation Studies}

the creation of calculative tools that juxtaposed financial value against social and environmental value. Finally, the article concludes with a summary of its key empirical findings as well as the delineation of its theoretical implications for related literature.

\section{The Pragmatist Study of Value}

\section{Value and Valuation Work}

It is widely acknowledged that the study of value in the social sciences has taken a pragmatist turn. It has rejected a long-standing understanding of the concept of value as a quality of worth that is either inherently possessed by an entity (Marx 2011) or that is imbued to an object based on actors' moral beliefs (Stark 2011; Helgesson and Muniesa 2013; Vatin 2013). Instead, the question of what counts is approached by a concern for how value in a setting becomes produced and so actualized by particular socio-material arrangements (Dewey 1939; Muniesa 2012). How this valuation work entails the negotiation, construction, and objectification of value then becomes the object of empirical study (Velthius 2005; Healy 2006; Styhre 2013; Strandvad 2014).

This pragmatist approach to value emerged from the study of markets, where the assignment of economic value to commodities is not assumed to automatically result from the intersection of supply and demand, as posited by neoclassical economics (White 1981; Callon and Muniesa 2005; Beckert and Aspers 2011). Instead, attention is given to the role of a market's constituent mechanisms, devices, and rules in the assignment of economic value to goods. This market infrastructure facilitates the act of valuation, by assigning specific qualities to goods, facilitating commensuration, and allowing for the valuation of commodities (Callon 1998; Callon et al. 2002; Espeland and Sauder 2007; Muniesa et al. 2007).

If markets exist when economic exchange between actors is made possible, then a pragmatist approach to markets investigates the conditions-cultural, relational, material, and otherwise-that allow for such felicitous exchange to take place (Granovetter 1985; DiMaggio 1994; Garcia-Parpet 2007). Particular attention in valuation studies is given to the work of market devices in this endeavor- "the material and discursive assemblages that intervene in the construction of markets" (Muniesa et al. 2007, 2). Market devices are critical to the valuation of commodities in the market. Drawing from the premise that economic exchange is only viable where there is an understanding on the qualities of goods, these calculative tools matter because they reflect, solidify, and perform a particular criterion of value for market participants (Callon 1998; Callon and Muniesa 2005). They also facilitate actors' determination of the value of goods by dispelling the challenge of uncertainty. Judgment devices, such as rankings, critics' 
judgments, and labels, perform valuation for use by market actors (Karpik 2010). Similarly, as Yenkey (2011) shows, the construction of a stock market in Kenya was contingent upon the establishment of calculative tools that could demonstrate the value of investments to potential participants.

But how do such socio-technical arrangements arise? Rather than view the "architecture of markets" (Fligstein 2001) as arising from an aggregation of individual members' exogenous and set preferences, the study of valuation has highlighted the role of actors in setting up the constituent components of the infrastructure of markets in ways that bring value into being by making valuation possible via calculative tools and calculative actors (Beunza and Garud 2007; Beckert and Aspers 2011; Vargha 2011). The determination of value in the nascent financial industry, for example, was beset by the indeterminacy of value but eventually, as the result of contestations and negotiations between members of the field, came to coalesce around a particular criterion of quality and set of calculative devices (De Goede 2005). Similarly, Preda (2006) delineates how a particular market device, the financial chart, came to be diffused and widely employed.

\section{Value Plurality and Concerned Markets}

An expanding body of literature has moved beyond the valuation work involved in the question of economic value to investigate how value plurality-the "concurrent co-existence of different valuations" (Helgesson and Muniesa 2013, 6) -is negotiated in markets. Here, value (in the economic sense) and values (in the moral sense) are not viewed as being located in "hostile worlds" (Zelizer 2005). Instead, each and every market is understood to incorporate multiple orders of worth, including economic, social, political, and cultural value (Boltanski and Thévenot 2006; Lamont 2012; Helgesson and Kjellberg 2013). For example, the determination of a good's economic value tends to result from the negotiation and translation of alternative orders of worth into an economic logic, as structured by broader political and institutional arrangements (Beckert and Aspers 2011; Styhre 2013; Geiger et al. 2014). Fourcade (2011) illustrates this analytical point in her comparative study of the assignment of a dollar value to the environmental degradation caused by oil spills in the United States and France. And markets contain value plurality in that economic value defines and contains prescriptions for the proper organization of social life inside and outside of the market (Smith 2007; Cooper et al. 2014). Ortiz (2013), for example, shows how professionals in the financial industry drew from and enacted moral and political beliefs in their decisions to extend access to credit to some clients but not others.

Value plurality is therefore widespread in all markets but is particularly apparent in the ongoing proliferation of new, hot markets, 


\section{Valuation Studies}

sometimes called "concerned" markets (Geiger et al. 2014) or "civilizing" markets (Callon 2009), that intentionally employ market exchange as a means to obtain both a financial and a non-financial end, which may be political, social, or environmental in nature. Examples include ethical consumption (O'Rourke 2005), carbon trading (MacKenzie 2009), and clean technology (Doganova and Karnøe 2015). As in the cases of the Fair Trade Movement or socially responsible investing (SRI), some of these markets are instances of what King and Pearce (2010) have described as the switch of social movements from their traditional focus on the state to contentiousness aimed at economic actors in the private sector. Elsewhere, the neoliberal emphasis on government privatization has led to powerful actors promoting market-based solutions to problems that had previously been deemed the responsibility of the government or civil society (Shamir 2008), including "Social Impact Bonds" (Cooper et al. 2014) and "Sustainable Investing" (Barman forthcoming).

No matter what their origin, these types of concerned markets are of theoretical interest for valuation studies because they explicitly highlight the centrality of value plurality in a market setting. How then does value/s get recognized, defined, and negotiated in concerned markets? What kinds of valuation work take place in a new market characterized by the intentional inclusion of value dissonance in its envisioning by proponents (Stark 2011; Antal et al. 2015)? One presumption in the valuation literature is a compromise-the consolidation of competing qualities around a single order of worth (Callon 1998; Boltanski and Thévenot 2006). More precisely, it may be expected that economization occurs in these types of markets (Çaliskan and Callon 2010): economic value becomes the dominant regime of value, given the ease by which a dollar value can be assigned even to "peculiar" goods such as natural resources, carbon emissions, or heritage sites (MacKenzie 2009; Fourcade 2011). In a financialized society (Krippner 2005; Muniesa 2012), prices represent the "best representation of the value of exchanged goods" (Ortiz 2013, 65).

Yet, this theoretical assumption is based on the study of markets where the economization of goods has already occurred and so leaves open the possibility of continued value plurality in other markets. A more recent approach has been to investigate instances of the ongoing presence of multiple regimes of value in a market setting (Beunza and Stark 2005; Stark 2011; Helgesson and Kjellberg 2013). In this line of action, the presence of competing qualities of goods in terms of valuation practices is approached as an empirical question, one open to different arrangements, negotiations, and relationships. Here, scholars have examined the "entanglement of apparently distinct or even incomparable value systems" (Moor and Lury 2011, 440), including the intertwining of economic and political value in the French funeral industry (Trompette 2013), the construction of a clean 
technology market in agriculture that reconciled environmental and economic value (Doganova and Karnøe 2015), and the intersection of monetary gain and sacred concerns in the construction of the life insurance industry in the United States (Zelizer 1983). Other work has investigated the conditions and configuration of calculative tools that valorize and so produce the coexistence of multiple regimes of value. These include the new accounting methodologies that gauge firms' social and environmental performance, including triple bottom line (TBL) and SRI methodologies (Power 2007; Hall et al. 2015).

\section{Methodology of the Study}

\section{The Case of Impact Investing}

The market of impact investing provides a suitable case for the investigation of these questions and debates over the presence of value plurality, as particularly evident in concerned markets. ${ }^{1}$ The employment of economic exchange as a means to financial and nonfinancial ends in the envisioning of impact investing allows for the study of how value plurality was understood and enacted by members of this market in and through the construction of a valuation infrastructure, including a reporting standard and a rating system. Impact investing is a relatively new type of finance market, first emerging in 2007, which is characterized by investors providing capital to companies and funds with the intention of generating social and environmental impact alongside financial return, ranging from principal to above market, in companies located in developed and developing countries that are "double bottom line" in nature. These locally owned and operated firms produce financial value for investors and generate social and environmental value through their business model, such as the production of entrepreneurship opportunities or financial services, the provision of quality employment, and/or through their sale of socially beneficial goods and services, such as financial services, education, healthcare, clean technology, or affordable housing, to underserved populations (J.P. Morgan 2010; Bugg-Levine and Emerson 2011). In 2014, the last year for which data was collected an estimated US\$10.6 billion was invested in this market (Saltuk et al. 2015).

Three sets of actors compose the impact investing industry: investors, intermediaries, and firms/funds. As with mainstream financial investing, impact investors include both asset owners and

\footnotetext{
${ }^{1}$ In focusing on the market of impact investing, this paper employs the case study method. The case study method is premised on the belief that in-depth, detailed, and comprehensive understanding can be derived from the empirical analysis of a single setting, as a "case" of a particular theoretical category (Eisenhardt and Graebner 2007).
} 
asset managers. Asset owners consist of individuals and institutions (such as clients of private banks, private family offices, community development institutions, and charitable foundations) who typically invest using the financial services of asset managers, including boutique firms, or mainstream firms who have separate offices focused on impact investing. Intermediaries in the market of impact investing include consulting firms, government agencies, foundations, and academics, who generate infrastructure and provide consulting and data to participants in the market. Investment opportunities consist of both local firms and investment funds that coordinate the provision of capital to those companies. These firms and funds qualify for impact investment if they offer a market-based solution to a social or environmental problem (J.P. Morgan 2010; Bugg-Levine and Emerson 2011).

By focusing on a firm's business model as a source of social or environmental value as well as economic value, impact investing differs from other long-standing types of ethically oriented investing. It diverges from SRI, a well-established form of investing that is characterized instead by the screening of firms based on the negative effects of their products on consumers or the consequences of businesses' production processes on stakeholders, often with the assumption that investment will not produce financial return. In its attention to the socially and environmentally beneficial impact of firms' business models, impact investing also departs from responsible or sustainable investing, where a firm's performance on environmental, social, and governance criteria is also highlighted but viewed only from a financial perspective as a material source of risks and opportunities that generate long-term shareholder value (Monitor Institute 2009; J.P. Morgan 2010; Bugg-Levine and Emerson 2011).

As noted above, impact investing constitutes one of a growing number of concerned markets where economic exchange is employed for the pursuit of financial gain as well as political, social, and/or environmental benefit, supplementing or supplanting traditional efforts by the public and nonprofit sectors (Callon 2009; Geiger et al. 2014). In the broader project of international development, impact investing -in its use of financial investing in order to achieve economic gain as well as social or environmental benefit-replaces a long-standing dichotomy between philanthropy (where resources are given away for social benefit) and finance (where resources are invested for economic value); it negates the "binary choice between investing for maximum risk-adjusted returns or donating for social purpose" (J.P. Morgan 2010, 5).

\section{Data and Methods}

This essay focuses on the negotiation of value plurality, in the form of the co-presence of economic value alongside social and environmental 
value, for the concerned market of impact investing. It asks whether and how this value dissonance was recognized, defined, and negotiated in the early and formative years of the market of impact investing. To do so, it analyzes the genealogy of the calculative tools constructed by intermediary actors in this setting, given that "value depends on how valuation is done, when, by whom, and for what purpose" (Muniesa $2012,28)$. The valuation infrastructure in this market consists of a reporting standard for firms' separate financial, social, and environmental value and a rating system that assigns stars to firms based on their social and environmental performance. Assuming a constructionist approach to valuation, the methodological approach used here is to outline the biography of these calculative tools as material objects (Kopytoff 1986; Desrosières 2001; Espeland and Stevens 2008).

To generate this biography of the market of impact investing's valuation infrastructure, the paper employs an extensive assortment of sources, including document analysis, field research, and qualitative interviews. First, I analyzed the content of documents and websites of organizational actors in the market of impact investing. I collected publicly available websites, published documents, and internet documents produced by members of this market, and gathered internal documents provided by the interview subjects. I also reviewed those websites that constituted, described, and diffused the calculative tools that made up the market's valuation infrastructure. I conducted document analysis of academic and media publications from 2007 to 2015 that were either written by or included quotes from market proponents or evaluators via a search of ProQuest.

I engaged in participant observation at three practitioner-oriented conferences, where some members of the market of impact investing made presentations and other members participated as attendees. These conferences, which respectively focused on the topics of social enterprise, sustainable investing, and social metrics, took place in the United States from 2010 to 2012. A growing body of scholarship views professional conferences as a space where actors make claims, contest over, and/or come to consensus concerning the field's identity through presentations and face-to-face interactions (Garud 2008). For each of the ten sessions where members of the market of impact investing presented, I took extensive field notes concerning both the content of each presentation and the follow-up discussion between presenters and attendees. While this data is certainly not representative of all conferences taking place in this market, these ethnographic observations provide a unique perspective by focusing not on the formal claims made by key actors to external audiences but by examining conversations and interactions occurring among professionals. 
Finally, I conducted interviews with respondents involved in the construction of the market and in the creation of its calculative tools. Interviews were informed by a semi-structured interview guide that included questions about the subject's professional background, the organization's history and goals, the history, purpose, and future of the market of impact investing, the meaning of value/s in the market, and discussed the origins, construction, and intended purpose of the market's valuation infrastructure. Two methods of sampling were used to select interview subjects. Purposive sampling was used first to identify respondents based on an initial review of publications as key actors in the formation of the market and the construction of its main calculative tools. I then employed snowball sampling to ask those initial respondents to recommend other salient members of the market for participation in my study. Interviews were conducted with twelve staff members of organizations in the market of impact investing, including (a) influential proponents of the market for impact investing $(\mathrm{n}=4)$; (b) professional staff who served as evaluators by constructing the reporting standard and the ratings system $(n=3)$; (c) early intermediaries in the market (including nonprofits, consulting firms, and academics) $(\mathrm{n}=4)$; and (d) early investors in impact investing (including charitable foundations, investment houses, and investment advisors) $(n=4)$. Some of the respondents served in multiple roles. While the sample size here is small, it includes the majority of actors involved in the formulation of the valuation infrastructure in impact investing, as described in interviews and in publications that recount the market's origins (Bugg-Levine and Emerson 2011; Lane 2015).

\section{Data Analysis}

These sources were not only evaluated in terms of how they presented the origins, meaning, and purpose of the market's valuation infrastructure; but several other critical dimensions were also evaluated, including the history provided about the market, the mention and meaning of value/s for impact investing, and the origins of and actors involved in the construction of the market and its valuation infrastructure. During the processes of data collection and analysis, I employed the "abductive method," which has been defined as the cultivation of anomalous and surprising empirical findings against a background of existing scholarship and through systematic methodological analysis (Timmermans and Tavory 2012). As I gathered and analyzed relevant sources, I drew from and returned to theoretical expectations and analytical concepts gathered from related literatures in valuation studies and economic sociology in order to derive and test propositions from this scholarship. As common issues and themes emerged, I employed an iterative methodology, returning to past empirical sources and theoretical claims, and comparing analytical concepts and categories across the units of analysis. 


\section{Designing the Market of Impact Investing}

To understand the question of value in impact investing requires attention to the activities of those actors who engaged in valuation work through the construction of the market's valuation infrastructure. In the scholarship, the work of "evaluators" is recognized to be particularly critical in the generation of calculative tools in a setting (Beckert and Aspers 2011; Bessy and Chauvin 2013). As one type of market intermediary, evaluators do not simply respond to existing understandings of value but also actively constitute it through their actions (Beunza and Stark 2005; Velthius 2005; Muniesa 2012). Through discursive work and/or the creation of calculative tools (such as ratings and rankings), these evaluators or "third parties" (Espeland and Sauder 2007) work to define and to assign value to entities in a market and to develop market devices which then "stabilize" that order of worth (Zuckerman 1999; Strandvad 2014).

Evaluators vary in their role and position in a market: while some engage in valuation practices and construct calculative tools as a professional project (Karpik 2010; Carruthers 2013), others work as experimenters in an "in vivo market" (Muniesa and Callon 2007) they are powerful actors who engage in ongoing experiments, tests, and evaluations of conventions and calculative tools that map onto and enact a financial theory of the market in question. One instance of evaluators as market designers occurred in the formation of the carbon market in Europe, where regulatory agencies, multilateral organizations, non-governmental organizations (NGOs), and other actors worked to devise an appropriate socio-technical arrangement (Callon 2009; MacKenzie 2009). This type of evaluator "brings things into being by assembling them in a particular manner (in a particular site, through particular trials, and for a particular audience)" (Muniesa and Callon 2007, 539).

Similarly, the formation of the market of impact investing, and its constituent calculative tools, can largely be traced to the work of the Rockefeller Foundation as a powerful actor who promoted and funded the market of impact investing, with observers identifying the foundation as the "organizing instrument" (Jackson 2013) or the "architect" of this new financial market (Stabile 2010). Established in 1913 by John D. Rockefeller, Sr., the Rockefeller Foundation is one of the largest charitable foundations in the world with an endowment of US\$3.7 billion in 2014 and a mission to "promote the well-being of humanity." The history of the Rockefeller Foundation has been characterized by a series of defining core initiatives intended not only to guide its own funding but also to shape broader efforts in the arena of international development, including catalyzing the growth of public health and spearheading the Green Revolution in agriculture (Cueto 1994). 
By 2000, the focus of the Rockefeller Foundation had shifted to the problem of global poverty, with an emphasis on fostering new strategies to alleviate economic inequality in the global South (Rockefeller Foundation 1999). In 2007, as part of that broader initiative, the Rockefeller Foundation committed to impact investing as a social project, premised on a particular theory of this new concerned market. Impact investing was viewed as a new and promising privatesector solution to social and environmental problems, superior to the traditional efforts of government and civil society actors. The specific rationales underlying the perceived virtue of impact investing, as offered in early publications by market advocates, were multiple, and demonstrated how financial markets are constitutively social in nature (Ortiz 2013). One source of appeal was derived from a theoretical modeling of the market where financial investors could obtain economic and social and environmental return on their investments, as opposed to the long-standing premises of modern portfolio theory. Another justification came from the broader claim that poverty and other social problems were best addressed by the inclusion of disadvantaged populations in the market. The final attraction of impact investing for market proponents derived from the scale of economic resources available in the finance market to address social and environmental challenges, as compared to the amount of aid historically provided by governments or NGOs (Godeke and Pomares 2009; Monitor Institute 2009; J.P. Morgan 2010; Palandjian 2010). In the words of Judith Rodin, the president of the Rockefeller Foundation who spearheaded the impact investing initiative:

We recognized, if you put a price tag on all the social and environmental needs around the world, it is in the trillions. All of the philanthropy in the world is only $\$ 490$ billion. So, the needs far exceed the resources. The one place where there is hundreds of trillions of dollars is in the private capital markets. So we, and others, began to wonder are there ways to crowd in private funding to some of these incredible needs (Kozlowski 2012).

Similarly, at one conference I attended on sustainable investing, a self-recognized impact investor (a partner in a small investment firm involved with for-profit health interventions in the global South), explained the appeal of impact investing at the start of his presentation, again by contrasting the scale of resources in the financial economy against those available in philanthropy, this time through a personal narrative. ${ }^{2}$

I think about myself and how I can make the world a better place. When I worked at [a large New York bank], I could take some amount of my income

2 In this paper, I refer only to the professional background and the role of respondents in impact investing in the construction of the market's calculative tools in order to protect the identities of the research subjects. 
and I could send it to a do-gooder nonprofit in the developing world ... But wouldn't it be even better if I could put a much bigger pool of money towards creating a better world? If I could take all this money that I've been investing just to make rich people even richer and invest it so they still get even bloody richer but so that also their money makes a difference. I would have access to so much more money that way and the scale of what could be done would be so much bigger, soooo much bigger. That's essentially the story behind [the name of his company].

With this philanthropic motivation behind its commitment to impact investing, the Rockefeller Foundation sought to put its weight behind the expansion of this new market. It recognized that the concept of market-based solutions to social and environmental problems was not new at the time: an assortment of distinct and uncoordinated types of markets already existed to address a specific social or environmental issue, including microfinance, community development, and clean technology (Godeke and Pomares 2009; Monitor Institute 2009; J.P. Morgan 2010). Microfinance, for instance, consists of the provision of financial services to low-income clients to whom traditional financial institutions have been unwilling to offer banking services. By 2006, over US\$25 billion was invested annually in U.S. institutions. Community development is a form of governmentregulated investment, whereby U.S. banks are encouraged to make investments available to low-income communities: in 2007, about US $\$ 26$ billion was invested in this market. With US\$148.4 billion of new investments by 2007, clean technology consists of finance capital directed to technological products aimed at environmental sustainability (Monitor Institute 2009).

The purpose of the Rockefeller Foundation in integrating these existing arenas into a single market was to increase the scale of impact investing by drawing into impact investing an entirely new type of investor-what publications and interview subjects called "mainstream" or "traditional" investors (Monitor Institute 2009; J.P. Morgan 2010). ${ }^{3}$ These investors historically had invested solely for financial return but they would provide a far greater amount of capital if they were to engage in impact investing, as opposed to the existing pool of impact investors. At the time, the majority of established investors in impact investing were charitable foundations in the United States, who were increasingly investing a small portion of their endowments in for-profit vehicles that furthered their social mission (Monitor Institute 2009; J.P. Morgan 2010).

\footnotetext{
3 The term "impact investing," coined in 2007, was intended by proponents to convey the integrative identity of the new market: it served as a "broad, rhetorical umbrella under which a wide range of investors could huddle" (Bugg-Levine and Emerson 2011, 8).
} 
In contrast, if the promise of impact investing initiative relied on the "unlocking" of the vast scale of private resources of mainstream investors available in the global finance economy, then the Rockefeller Foundation, along with other advocates of the market, realized that it needed to access that much larger "untapped" pool of finance capital, to quote from one senior staffer at the time. The goal was to "expand the community of Impact Investors" beyond charitable foundations and other long-time impact investors and to incorporate mainstream investors in order for impact investing "to move from niche to mainstream" (Palandjian 2010, 2). In the words of the chief operating office of a nonprofit private equity fund already active in impact investing: "All of us fantasise about capital flowing to the space from retail investors and public equity and professional money managers" (Stabile 2010).

\section{Targeting Mainstream Investors}

The Rockefeller Foundation began a concerted effort to learn more about this type of investor and how impact investing could be made appealing to them. First, in 2007, the foundation convened a small meeting of impact investors to learn more about these actors' understandings of the potential and challenges of growing this market by the inclusion of a new type of investor. In 2008, the Rockefeller Foundation committed US\$38 million to market design and experimentation (Lane 2015). That year, a portion of that money went to a more comprehensive study of the needs of investors, both current and potential, again with an eye to attracting mainstream investors to impact investing, including interviews with investors "about their experience with investing for impact, how they think it may evolve, and what will best accelerate its evolution" (Monitor Institute 2009, 6).

Here, in contrast to theories of market formation that focus on the activities of suppliers (White 1981), it was apparent that the Rockefeller Foundation focused on the needs of investors when envisioning the future success of this new market. An emphasis on investors as consumers in this finance market mirrors other literature within the pragmatist approach to value and valuation (Yenkey 2011), including studies of qualification-the process by which a market reaches consensus on the identifying properties of goods in a market (Callon et al. 2002; Callon and Muniesa 2005). For those actors, including intermediaries and suppliers, involved in the qualification of goods, consumers are the targeted audience: "what is sought after is a very close relationship between what the consumer wants and expects, on the one hand, and what is offered, on the other" (Callon et al. 2002, 202). In an interview with a long-time impact investor who had participated in the Rockefeller Foundation's focus groups, the respondent similarly noted: 
From the start, the Rockefeller staff clearly were interested in the demand side of growing impact investing. You could see that really clearly in terms of who was invited to their retreat in Bellagio [the location of the first 2007 meeting] and so it wasn't until later that their attempt to build the market included an effort to pay attention to the supply side. (Interview with early impact investor)

By this stage, the Rockefeller Foundation had accumulated a wealth of knowledge about the perceived problems and challenges entailed in establishing a market of impact investing which would appeal to traditional investors. Two aspects of this data were most relevant for understanding the subsequent valuation work sponsored by the foundation. First, whether emic and/or etic in origin, the 2009 report was characterized by the extension of mainstream financial theory to the case of impact investing as a finance market. At the heart of the publication was a claim that the scale of resources invested in this market would only grow if the market shifted from "fragmentation" (characterized by distinct finance markets-e.g. microfinance, community development, and clean technology) to "maturity" (in which a single market infrastructure would facilitate market efficiency). Until a mature market was created in which demand and supply was aligned and transaction costs reduced, mainstream investors would not participate in impact investing. As an early seminal report concluded:

The pressing question is whether impact investing will remain a small, disorganized, underleveraged niche for years or even decades to come-or whether leaders will come together to fulfill the industry's clear promise, making this new domain a major complementary force for providing the capital, talent, and creativity needed to address pressing social and environmental challenges. (Monitor Institute 2009, 5)

Second, the report then drew from the "lessons" of successful emerging industries, including venture capital/private equity, to identify the barriers that needed to be removed to enable the market's transition, given that "mainstream players" will only enter a "functioning market" (Monitor Institute 2009, 12). Three challenges were recognized as central to the success of impact investing, of which one consisted of the lack of an "enabling infrastructure" to facilitate this new type of investment for traditional investors. In this last concern, the issue of value-of what counted as value/s in the market, how the value of investments could be evaluated by investors, and via what types of calculative tools-was considered by the report's authors to be a central problem that had to be resolved if the industry was to grow into a mature market (Monitor Institute 2009). 


\title{
The Dissonance of Financial versus Social and Environmental Value
}

The question of "what counts" in this report was approached from the perspective of investors. Impact investors, current and future, were argued to differ in terms of their understanding of the act of impact investing in regard to the relative importance of achieving financial return as compared to the importance of achieving social and environmental return. Drawing from interviews with investors and other members of the market, the report categorized impact investors as of two types: "impact first" investors (who "optimize social or environmental impact with a financial floor") and "financial first" investors (who "optimize financial returns with an [environmental/ social] impact floor") (Monitor Institute 2009, 32). In other words, some investors were willing to sacrifice an amount of financial return in order to achieve their intended social or environmental change (i.e. existing impact investors like charitable foundations), while others were not willing to make any or only a little financial sacrifice to do so (i.e. mainstream investors who would begin to engage in impact investing).

For both groups, social and environmental value mattered as a distinct regime of value from financial value, albeit in different ways. For "impact first" investors, the relative salience of financial value in the investment process depended on the amount of social or environmental value produced by an investment (Brandenburg 2010; J.P. Morgan 2010). For this group, "financial return became 'just one variable that an investor can readily and knowingly trade for another, such as mitigated risks or enhanced social impact" (Thornley and Daily 2009,14). As one staff member with the impact investing initiative at the Rockefeller Foundation explained:

\begin{abstract}
Some investors like foundations are willing to give up financial return if they know that they will be making a huge social impact. And, you probably know this already, but when a foundation makes a[n] MRI [Mission-Related Investment], it might worry about proving its social impact, like a worry about potential [Internal Revenue Service] or media scrutiny of what they're doing? So then, when you think about all of that, being able to measure the social return of an investment, alongside a consideration of financial return, was then crucial to continue to grow that portion of the market. ${ }^{4}$ (Interview with market proponent)
\end{abstract}

In contrast, for "financial first" investors, proof of social or environmental impact was needed to legitimate their engagement with

\footnotetext{
${ }^{4}$ In the U.S., mission-related investing occurs when foundations invest a portion of their capital assets in a socially or environmentally oriented manner, such as the use of negative screening, shareholder advocacy, or impact investing. Such investments typically are subject to a more flexible expectation as to their rate of financial return. Mission-related investing had by the 1990s become a growing practice among large foundations, including the Rockefeller Foundation (Godeke and Pomares 2009).
} 
impact investing, as compared to mainstream investing. Mainstream investors (and their advisors) were concerned about the potential trade-off of financial and social value. ${ }^{5} \mathrm{~A}$ staff member at a large consulting firm that had participated in the market's early history outlined that:

There was a general perception that the typical wealthy investor-someone who'd made his money on Wall Street and now was thinking about his legacy ... He might want his financial investments to align with his social values but-and here's where it gets tricky-the problem was that he also was operating within a broader culture in investing ... that put all its emphasis on fiduciary duty, and there was this general worry that if this fictional, archetypal investor was going to dip his toe into impact investing, he needed to be damn sure he was doing it for a good reason because there was this persistent belief that you couldn't do good and do well at the same time. He was ready to not make quite as much money as he could, but he was goddamn going to need some proof that he was saving the world to do it. (Interview with early intermediary)

For market advocates, this 2009 report on impact investing conclusively demonstrated the presence of multiple segments of impact investors, who held contrasting worldviews as to the relative salience and relationship of financial and social value. For the market to attract both of these types of impact investors, financial value would need to be kept juxtaposed and dissonant from social and environmental value as different regimes of value.

\section{Multiple Values without Manifold Valuations}

But, if maintaining multiple regimes of value were deemed critical to the growth of the market, then the question of valuation and valuation work in this new setting also became manifold. Investors-it was claimed-needed to be able to gauge the value of an investment along each distinct dimension. Yet, the seminal 2009 report argued that-in the market's current configuration-mainstream investors possessed difficulty in gauging the social or environmental value of investments, especially in their capacity to compare investment options. Drawing from the premises of finance theory, investors' perceived uncertainty represented a barrier to the growth of impact investing, unlike the estimation of financial value, where calculative tools and conventions

\footnotetext{
${ }^{5}$ In addition, an institutionalized measure of social impact was viewed as critical for legitimating the emerging market against the charge that it was oriented only around the pursuit of profit (Brandenburg 2010). The 2009 report concluded that the formation of calculative tools would "help protect the credibility and reputation of the field from conventional investments being promoted as impact investments" (Monitor Institute 2009, 47). In the words of one academic advisor to the field that I interviewed, "what GIIN is worried about is that impact investing is seen by others as a way to greenwash mainstream investment in a world that's increasingly critical of globalization."
} 
were already in place for investors. One "critical success factor" for the market was that investors need to "know what they are paying for" in terms of achieving their "social or environmental objectives" (Monitor Institute 2009, 37). Correspondingly, one of the staff at the Rockefeller Foundation at the time recounted that "the general impression was that new investors felt they were cognizant of how to do financial due diligence on an impact investment, but they didn't know how to do the social due diligence." And, to quote from one senior staffer of an early impact investment fund who participated in this process:

\begin{abstract}
We realized really soon that we needed a way for investors to figure out how much social impact they could have so that they could compare different investment possibilities. Up to this point, impact investors, like the Rockefeller Foundation say, had been doing this on their own-they had a whole staff devoted to measuring the impact of their donations who then also measured the impact of investments, but there was a sense that someone in the mainstream investing world would not be willing to spend the equivalent time and energy to do so, much less be savvy enough without a background in philanthropy or development. Without someone doing it for them, impact investing would never get to scale. (Interview with early impact investor)
\end{abstract}

This problem of valuation could be removed with the construction of "reliable social metrics"-calculative tools that would facilitate the valuation of the social and environmental "impact" of investments for investors (Monitor Institute 2009, 15). The report's authors looked to "metrics" already present in mainstream financial markets as models for impact investing, given their perceived critical role in the success of those established markets. In one quote from an executive at Merrill Lynch who participated in the study, the report stated: "Imagine a commercial investing world in which there weren't any ratings agencies, or quantitative or qualitative risk measures: there would be no money coming into this world" (Monitor Institute 2009, 66). In contrast, parallel market devices to gauge firms' social and environmental value were absent in the existing practice of impact investing. ${ }^{6}$ As one lead evaluator at the Rockefeller Foundation retrospectively summarized: "This type of basic market infrastructure exists for purely commercial investors (GAAP, Moody's, basic portfolio management tools), but had yet to be built for the 'impact' dimension of impact investing" (Brandenburg 2012, 2).

If traditional finance markets were dependent on those calculative tools to thrive, then equivalent market devices to measure companies' social and environmental value were needed for the market of impact

${ }^{6}$ The report noted that alternative calculative tools were present to measure the social behavior of firms, but only in other fields (such as socially responsible investing) that were based on different models of how businesses could affect social change (Monitor Institute 2009). 
investing to expand to the desired scale. As staff at the Rockefeller Foundation proclaimed: "without standards and ratings, investors can't distinguish between good investments and bad ones" (BuggLevine et al. 2012, 6). Another participant in this process avowed that if such infrastructure was put in place, "investors will then be able to make decisions based on personal values rooted in facts that balance the financial, social, and environmental impact because we will have the supporting ecosystem behind what is being measured and reported" (Pressner 2009).

As is clear, traditional investors were the intended users of these tools, demonstrating, as has been noted by others (Young 2006; Vargha 2011; Muniesa 2012), that valuation work is not simply technical in nature but also a communicative act. It is a "situated activity aimed at establishing a value for a particular actor and purpose" (Moor and Lury 2011, 440). Here, market proponent's efforts in this regard were "absolutely meant to build a market for the for-profit investing world to participate," noted one senior executive who led the design of IRIS (Impact Report Investment Standards) (Stabile 2010). For market proponents, the intended result of this experiment with new calculative tools would be that traditional investors' concerns would be addressed and they would then be more likely to invest in the new market (Monitor Institute 2009). The current level of impact investments, according to two advocates of the market at the time, "could be much greater if there were a way to more clearly measure the good that came from these investments; with such a measure, more capital would flow to that activity" (Hagerman and Ratcliffe 2009, 44). At one conference on social metrics that I attended, an early participant in the construction of this valuation infrastructure stated that developing "consistent metrics in the industry" would "drive impact investing to become a truly effective capital market." Developing this valuation infrastructure, as predicted by the pragmatist approach to value, would do much more than simply measure the social and environmental value of investees, instead, as scholars have noted, valuation here would bring about or make that value for investors (Dewey 1939; Muniesa 2012; Helgesson and Muniesa 2013), facilitating the broader project of "unlocking" mainstream capital for impact investing.

\section{Constructing Calculative Tools}

In its articulation of a formal model of the market of impact investing, the 2009 report authorized the Rockefeller Foundation to administer and fund the construction of the market's necessary market devices. After another meeting of investors, two types of calculative tools were decided upon as critical to the success of this new market: a reporting standard to define and measure firms' social and environmental value 
and a ranking system to evaluate investment firms and funds' social and environmental performance (Bouri 2011; Lane 2015). These calculative tools were to be modeled after parallel market devices present in traditional "capital markets" to estimate firms' financial value. But, in the process of adjusting these devices to this new market, these tools would be modified so as to only incorporate companies' social and environmental value, entailing its own distinct set of challenges.

\section{Commensuration via a Reporting Standard}

The first experimental calculative tool was the creation of the IRIS. Developed by a Rockefeller-sponsored nonprofit called the Global Impact Investing Network (GIIN), this market device was intended to address the recognized problem that impact investors did not have access to uniform terminology and consistent data on firms' social and environmental performance, thus making it difficult for investors to compare investment alternatives (Monitor Institute 2009; J.P. Morgan 2010). In one interview, I asked an evaluator involved in the construction of IRIS to describe the rationale for its formation, and she recalled:

There was this general sense that investors were dealing with inadequate datawhat they needed to invest was apples to apple data. So if you were an impact investor you could look at the firm and check its financials to see about its fiscal health-is it making a profit? And then you'd try and do something equivalent for its social impact. But basically what was happening was that, for example, an investor who wanted to invest in getting women into the market-like by selling their crafts-would look at available data to try and assess the different social enterprises' social impact. So if social impact was defined as these women actually getting income from the sale of their goods, then one social enterprise might measure it one way-say by the number of items sold-while another might measure it by total annual income earned. This was happening all the time and there would be no way to see which firm was having the most success, having the most social impact. (Interview with evaluator)

As illustrated in this quote, companies that pursued similar goals were understood to be measuring their social value in different ways, leading to a lack of capacity for comparability for investors: IRIS was constructed by evaluators to overcome this challenge. As a reporting standard, IRIS was created for evaluators to play the same role in impact investing that the GAAP or the International Financial Reporting Standards (IFRS) play in mainstream investing (J.P. Morgan 2010; Bouri 2011). "IRIS" stated one senior executive at GIIN, the nonprofit charged with developing the reporting standard, "is intended to be analogous to GAAP: which reporting framework you use develops on which type of value you are trying to gauge." In mainstream investing, GAAP and IFRS each constitute a standardized framework for companies' employment when they construct their financial 
statements. They are intended to provide investors with equivalent terms and indicators to generate comparable information about firms' financial performance. In its transposition to impact investing, this new reporting standard was to be used by firms and funds to annually report on their financial, social, and environmental performance, with the resulting data to be used by investors for their own tailored needs, to be aggregated by intermediaries for benchmarking, and to be employed by rating systems (Brandenburg and Gelfand 2009; GIIN 2015). In this view, IRIS would produce data that would "enable impact investors to compare investments against their peers - a capacity that proved central in the growth of mainstream venture capital and private equity" (Godeke and Pomares 2009, 122).

Theoretically, IRIS's central purpose was to facilitate commensuration-the "measuring of different objects with a common metric" (Espeland and Stevens 1998, 408). Commensuration entails the standardization of goods: they must be made "common-the opposite of being uncommon, incomparable, unique, singular and therefore not exchangeable for anything else" (Kopytoff 1986, 69). The commensurability of entities can take the form of the assignment of price but it can also occur through the construction of common non-economized units of measurement, as in the case of universities being made comparable by a growing assortment of third-party ranking systems (Espeland and Sauder 2007).

However, reflecting the disparate origins of impact investing in multiple markets, the widely recognized challenge was that no single meaning of the regime of social and environmental value existed among investors - the targeted users of the proposed standard. Instead, evaluators perceived that investors defined and so measured social and environmental value in a multitude of ways. Value plurality, in other words, existed in the market of impact investing not only in terms of the presence of the multiple regimes of financial, social, and environmental value, but also in terms of the presence of various conceptions of social and environmental value, each entailing a different meaning and corresponding metric/s of value.

The seminal 2009 report on the market of impact investing, for instance, concluded that "impact investing is both one thing, and many things," listing clean technology, microfinance, global health, job creation, and small and medium enterprises (SMEs) in developing countries, as well as community development in the United States as constituent practices of impact investing (Monitor Institute 2009, 6). An early advisory text to potential impact investors, produced by an affiliate of the Rockefeller Foundation, gives a sense of the disparate nature of social and environmental value in the markets, with the authors asking the reader: "What issues will your impact investing address? Do you want to address widespread global problems such as poverty, disease or climate change, or would you rather focus on 
specific or domestic issues like literacy, local education or affordable housing? Geographic choices must also be made as well" (Godeke and Pomares 2009, 24). Such variation across investors' investment choices made the production of comparable data difficult. A staff member at a smaller foundation that was an early intermediary in the field and that participated in the creation of IRIS noted:

Overall, impact investing is about the quest for "public goods" through private means. But what that social impact looks like is investor specific. For example, one might want rural electricity in Africa while another might care about water sanitation for villagers in India. Other investors, like [name of an established impact investing fund] might think social impact arises when the very poor obtain employment. The problem is that if we just count the number of customers who receive rural electricity, you omit a count of the other kinds of social changes that other investors care about. How do you make different kinds of social impact comparable? Can you make them comparable? (Interview with intermediary and evaluator)

Given the multiple meanings and metrics of social and environmental value that existed among investors in the market, ranging across sectors, beneficiaries, and geographies, the question that arose for evaluators was how to construct a single reporting standard for the market that would allow investors to engage in comparison across firms and funds. ${ }^{7}$ One possibility, as suggested by the economics of conventions literature (Boltanski and Thévenot 2006), would be to "construct a compromise across the contested values and multiple logics of action" (Huault and Rainelli-Weiss 2011, 2). Similarly, commensuration typically involves the prioritization of one quality of worth over others: it "can be understood as a system for discarding information and organizing what remains into new forms. In abstracting and reducing information, the link between what is represented and the empirical world is obscured and uncertainty is absorbed" (Espeland and Stevens 1998, 317).

For proponents of impact investing, the concern over creating a standard that enacted a single meaning and metric of social and environmental value was that it would capture the type of social value envisioned by some investors but not others. The 2009 report on the

\footnotetext{
7 In result, the challenge of social and environmental valuation in impact investing differs from that of the recognized complexity of financial valuation in mainstream financial markets. In the case of mainstream financial markets, evaluators largely concur as to the underlying meaning of financial value (in terms of the production of shareholder return) but disagree as to how to measure it, electing from among an assortment of data and ratios to choose those that best signal a firm or stock's future financial value (Beunza and Stark 2005; Beunza and Garud 2007; Ortiz 2014). In contrast, actors in impact investing hold not only competing understandings of which data and ratios would best represent/capture a firm's social value but also possess different definitions of the underlying meaning of social value, as discussed herein.
} 
future of the market concluded: "We need to find a metric that preserves each investor's flexibility at driving toward their individual impact investment objectives" (Monitor Institute 2009). In result, a compromise in the form of an overarching metric was deemed unfeasible. In an illustrative interview, a staff person involved in the creation of the reporting standard recalled why it did not entail a single, broader metric of social and environmental value. She stated:

We had so many arguments over this. We knew we couldn't just use the metrics from one sector and ignore other metrics, cuz then we were leaving out some kinds of impact investing. So it had to be something that transcended those differences. And there were some options out there. There's a foundation or nonprofit maybe in London that converts different kinds of social benefits into a single measure of clients' improved human rights. That sounded really cool but really we were worried that human rights is kind of an esoteric topic for some. And there's SROI [Social Return on Investment], which assigns a monetary value in terms of the government savings that result from a social enterprise's work with clients, but that one folds social value into a financial measure so you can't tell precisely what is a firm's social impact. So none of those worked either. If you have a better idea, let me know since we couldn't and still can't figure it out. (Interview with evaluator)

Given these concerns, the solution for these evaluators was to create an inclusive reporting standard that incorporated the multiple existing meanings and metrics of social or environmental value as they were already enacted in practice by impact investors (as based on interviews with investors). The resulting reporting system, labeled the Impact Reporting Investing Standard (IRIS), included over forty existing taxonomies and reporting standards of social and/or environmental value from established impact investing markets, including community development and microfinance, with staff also working with "evaluation experts" to generate new standards for those markets recognized as integral to impact investing but lacking established metrics (Bouri 2011). Further, at conferences that I attended, GIIN staff repeatedly encouraged the submission of other existing metrics of impact investment that currently were overlooked by IRIS for future inclusion in the reporting standard.

As presented on the IRIS website, these metrics captured the varied and multiple dimensions of social value present across investors and firms in the market. In an early iteration of the reporting system, the "commonly reported impact terms" included an organization description (its mission, operational model, and location); product description (a firm's products, services, and target client base); product impact (the benefits produced by products and services); operational impact (a firm's policies, employees, and environmental performance); and, finally, financial performance (financial performance metrics 
consistent with GAAP and IFRS (IRIS 2011)). ${ }^{8}$ Each of IRIS's resulting over 400 metrics was based on an operational definition (although guidance on measurement was sometimes provided), based on the firm's salient policy, practice, or output (the number of goods/services provided or individuals assisted). Some of these metrics were required reporting for all companies. One example of a universal or "crosssectoral" metric was "Permanent Employees," defined as the "number of people employed by the organization at the end of the reporting period." Other metrics were required reporting only for companies in a specific social or environmental sector. For example in the sector of "energy, environment, and water," "Potable Water Produced" was defined as the "amount of potable water produced during the reporting period" (IRIS 2011; Hayat 2013). The result of such an inclusive reporting standard was that firms and funds could be required to report on as many as 170 different metrics of their financial, social, and environmental performance (Simon and Barmeier 2011).

\section{Valuation via a Rating System}

Yet, while IRIS created the capacity for commensuration, a second calculative tool was deemed necessary that performed the act of valuation for investors. Here, the concept of valuation refers to a social practice concerned with assessing and so valorizing the worth of salient entities according to a particular quality of worth, or what sometimes is also called evaluation (Helgesson and Muniesa 2013; Vatin 2013). In 2011, the Global Impact Investing Reporting System (GIIRS) was created by an independent nonprofit, called the B-Lab, with funding and sponsorship from the Rockefeller Foundation. First conceptualized in 2008 by market proponents, the rating system was intended to evaluate investment opportunities for investors according to their "social impact" (Bugg-Levine and Emerson 2011). As one staffer at B-Lab, the nonprofit, noted, "While IRIS created the capacity for comparison, it doesn't actually provide an impact rating for companies or funds while our product provides exactly such a judgment."

The idea of a rating system for social impact was motivated by market proponents' perception that the lack of rating system served as a barrier to mainstream investors' participation in impact investing, as noted above (GIIRS 2010). In this view, investors

need to know not only that everyone calculates metrics like carbon tonnage or defines terms such as "low income" the same way, but also how those reported metrics stack up against those from comparable companies and against a

8 The inclusion of metrics of financial performance here was intended to ease investors' evaluation of firms by "incorporating all necessary factors into a one-stop shop kind of thing," as summarized by a senior staffer at GIIN. 
generally accepted set of benchmarks for low, medium and high impact investments. (Krogh 2009, 17)

Again, as with IRIS, the intended users were mainstream investors who would be assisted in the act of impact investing. As the cofounder of BLab asserted: "The core users will be institutional or high net worth investors or fund managers or entrepreneurs in the impact investing world" (Stabile 2010). The development of a rating system, it was posited, would result in their entry into the market of impact investing. A managing director at Rockefeller Foundation involved with the impact investing initiative proclaimed: "credible social ratings like GIIRS will be crucial to enable mainstream investors to convert their growing interest in impact investing into action" (GIIRS 2011,2).

As with IRIS, this calculative tool was modeled after an existing market device in traditional capital markets. GIIRS was intended to be equivalent to established ratings systems in the mainstream financial industry, including Morningstar's ratings of mutual funds and Moody's credit ratings. A respondent outlined to me: “Think Standard \& Poor's but for social and environmental impact. That's what they were aiming for." These ratings agencies provide investors with what the evaluators posit to be independent and objective valuations of the capacity of debtees or investees to meet their fiscal responsibilities. These ratings serve as "judgment devices" (Karpik 2010) for mainstream investors, with these calculative tools performing the otherwise complex and ambiguous act of financial valuation for them.

Similarly, GIIRS was intended to serve a similar judgment function for impact investors but in regard to the social and environmental value of impact investees. By assigning a single score and a number of stars to investees, this rating system performed valuation for investors by reducing the complexity, ambiguity, and effort otherwise entailed in the act of valuation of impact investment options. A staff member at a consulting firm with a long-time history in the market described GIIRS to me as a "user-friendly shorthand" and as an "accessible shorthand" for investors to "know which investments will best give them the type of social impact they're after. Its strength is its ease of understanding." A senior executive at the Rockefeller Foundation outlined: "The idea is for investors who don't want to go deep into the data to have a service that does that on their behalf to scale this industry and allow it to grow" (Chang 2014). In addition, following one justifying rationale of rating agencies in mainstream finance, GIIRS was framed as an independent and objective third-party source of data. Ratings, it was claimed, were based on uniform and comparable data based on IRIS indicators. The rating system also emphasized its reliance on transparent and verified data, complete with an audit and assurance process. While companies self-report their survey responses, the data was reviewed by a large accounting company as a third-party 
verification service provider before the company received a rating. Finally, the rating system was also touted as "independent," as the ratings methodology is overseen by a separate board, composed of industry experts (GIIRS 2010, 2015).

As with IRIS, the evaluators who constructed GIIRS needed to negotiate the multiple meanings and metrics of social and environmental value present in the broader community of impact investing. Their solution both paralleled and departed from that of IRIS. On the one hand, evaluators' resolution of the challenge of value complexity was to incorporate a wide range of different dimensions of social and environmental value into the rating system. The GIIRS website, for example, states that the rating system is "holistic" and recognizes that "a company has multiple paths to impact" (GIIRS 2015). In an early iteration, GIIRS required each company to complete a self-reporting survey of 160 questions about their salient policies and practices in order for the rating system to have adequate data to gauge their performance (GIIRS 2010).

On the other hand, GIIRS as a rating system did engage in the reduction of information required to produce commensurability by evaluating firms according to a relatively limited criteria of social and environmental value. Reflecting the existing mission of the nonprofit charged with developing GIIRS (Bouri 2011), these evaluators drew from both impact investing's emphasis on firms' business models as a source of social or environmental value and the definition of social and environmental value found in the field of corporate social responsibility CSR), which-by the 2000s-had come to emphasize firms' treatment of stakeholders, governance practices, and (as with impact investing) environmental performance (Barman forthcoming). Accordingly, an early version of GIIRS included five key dimensions of firms' behavior, including a firm's "leadership/accountability" (its governance policies and transparency of reporting); "employees" (its compensation and benefits, the extent of employee ownership, and the safety of the work environment); "environment" (its environmental policies governing its corporate offices, transportation/distribution of goods, and manufacturing facilities); "community" (its engagement with local communities and its supply chain, its policies ensuring diversity, and its philanthropy guidelines); and "products \& services" (its sale of beneficial products and/or services to those in need) (GIIRS 2010).

GIIRS assigned points for companies' possession of the desired policy or practice in each regard and then aggregated a firm's numerical score on each of these five criteria. As one early guideline outlined: "A company begins the assessment with zero points and earns incremental positive points for each positive impact policy, practice and achievement" (B-Lab 2011, 6). Drawing on this quantitative measure, the rating system then assigned a percentage and 
a number of stars (out of five) to a firm in order to communicate its social and environmental value to investors. These scores could thenevaluators suggested in their publicity material-be comparatively employed by potential investors hoping to identify those opportunities that provided the most social and environmental return, further tailored on an interactive website to an investor's specific interest, including a particular "impact" area (e.g. gender equity, environment, or health), industrial sector, geographic region, or organizational size (GIIRS 2010, 2011).

\section{Concluding Remarks}

In this paper, I have analyzed impact investing as a case of a concerned market where economic exchange is promoted as a means to pursue both financial and social or environmental value. Methodologically, I employed the established strategy of studying the early history of this market (Callon 2009; Huault and Rainelli-Weiss 2011; Doganova and Karnøe 2015), premised on the assumption that in such a setting, "values and valuations are subject to controversy or otherwise explicit contemplation" (Helgesson and Kjellberg 2013, 366). Drawing from a pragmatist perspective (Dewey 1939; Muniesa 2012), I sought to account for how the centrality of value plurality to this market was recognized, defined, and negotiated, by offering a genealogy of the market's calculative tools. These market devices, including a reporting standard and rating system, valued and so valorized the social and environmental value, as distinct from the financial value, of firms and funds as investment options.

The case of impact investing thus provides a compelling contribution to scholarship on the role of the market in contemporary society. As has been noted by other scholars, financialization, and its attendant emphasis on shareholder value, characterizes an increasing array of societal spaces (Krippner 2005; Ortiz 2014). In the case of impact investing, the reach of the finance economy similarly is now extended to socially and environmentally beneficial goods and services that historically have been the provenance of the state and/or civil society. Impact investing constitutes one concern of observers of this new market, and a parallel expectation of theoretical scholarship has been that social and environmental value, as distinct regimes of value, will be subjugated to the logic of the market through the assignment of financial value to investment opportunities based on their production of shareholder value, or what is called "capitalization" (Muniesa 2012; Ortiz 2014).

In contrast, as evident in the calculative tools that have been deployed in this setting, the capitalization of all types of value has not occurred in this setting. While impact investing entails the extension of finance to a new societal space, it has not entailed the capitalization of 
firms' social and environmental value via reference to their economic worth for shareholders. Instead, the ensuing measure and meaning of value in impact investing remains multiple, as intended by the market's initial experimenters in their envisioning of impact investing and so constitutes a case of value dissonance, where the presence of multiple qualities of worth "co-exist in a space without any mutuality apart from temporal and spatial co-presence" (Kjellberg et al. 2013, 22). This juxtaposition aligns with some concerned markets (Doganova and Karnøe 2015), such as the market of weather derivatives (Huault and Rainelli-Weiss 2011), while standing in contrast to others, where consolidation around an economic order of worth occurs and a price is assigned to goods, as in the case of carbon markets or fair trade goods (MacKenzie 2009; Reinecke 2010).

Accounting for the ongoing presence of value complexity in impact investing constituted an accompanying task of this essay, thus extending our theoretical understanding of the conditions underlying the role of value in markets. Drawing from the broader literature on the role of market intermediaries as evaluators (Velthius 2005; Beckert and Aspers 2011; Bessy and Chauvin 2013), the paper framed the construction of this socio-technical arrangement as among several experiments conducted by powerful proponents to establish the market of impact investing, akin to the experimental efforts that have occurred in the design of other civilizing markets (Muniesa and Callon 2007; Callon 2009). The social project of these powerful advocates, in the sense of addressing social and environmental inequities, was to scale this new market as a private, neoliberal solution to social and environmental challenges in the developing and developed world. Doing so, in this case, would require the entry of mainstream investors into the market, and so attention was given to assessing the worldview of those precise actors, so that their concerns over impact investing (as premised on its dual pursuit of economic and social or environmental value) were to be mitigated.

The recognition that actors' worldviews matter for understanding the negotiation of value in a setting is not new (Boltanski and Thévenot 2006; Huault and Rainelli-Weiss 2011). However, the specific way in which mainstream investors' conceptions of value mattered in impact investing does provide an innovative contribution to this scholarship. In contrast to the predictions of extant literature, the juxtaposition that arose between financial value as opposed to social and environmental value in setting did not result from market members' moral concerns that the pursuit of economic gain would crowd out other qualities of worth (such as those based on equality or collective welfare) (Healy 2006). In the case of impact investing, the use of market methods and finance capital to address social and environmental problems was not perceived by investors as a case of "hostile worlds," whereby the pursuit of non-economic value was put 
in threat by its presence in the market (Zelizer 2005). Instead, investors in this market embraced the plurality of values present in impact investing and expressed no moral discomfort with the simultaneous pursuit of economic value alongside social and environmental value.

Having estimated mainstream investors' perspectives on impact investing, market proponents then sought to address the perceived barriers to their engagement in this new market, with attention given to these actors' emphasis on the ambiguous and opaque quality of the social and environmental value of impact investments. Drawing from the theoretical model underpinning and the calculative tools employed in established financial markets, market proponents acted as evaluators by extending the market devices present in mainstream finance to this new market. The task was to employ analogous judgment devices in impact investing in order to perform the tasks of commensuration and valuation for investors without economizing the social and environmental value of firms in the sense of capitalizing their worth for shareholders. In all, the success of proponents' efforts to frame and structure impact investing as a financial market was contingent upon the construction of calculative tools that did not economize social and environmental value but rather brought it into being as a distinct regime of value, alongside financial value.

By addressing the question of how value plurality was identified, defined, and negotiated in the market of impact investing, this paper has responded to the call "for continued work on how to conceptualise the simultaneous dealing with multiple values as part of market practice" (Helgesson and Kjellberg 2013, 367). In tracing out the history of this market's valuation infrastructure, it has sought to demonstrate that calculative tools are material objects by which both are constituted and which bring about multiple regimes of value in concerned markets, as one illustration of a pragmatist approach.

Acknowledgements. For helpful comments, I would like to thank Julian Go, Claes-Fredrik Helgesson, Ashley Mears, and anonymous reviewers at Valuation Studies. Versions of this paper were presented at ARNOVA, Emory University, the Society for the Advancement of Socio-Economics (SASE), and the Stockholm Centre for Organizational Research (SCORE); the paper benefited from the feedback I received. Finally, I am grateful to those individuals who took the time from their busy schedules to speak with me about their work in impact investing. 


\section{References}

Antal, Ariane Berthoin, Michael Hutter, and David Stark (eds). 2015. Moments of Valuation: Exploring Sites of Dissonance. New York, NY: Oxford University Press.

Barman, Emily. forthcoming Caring Capitalism: The Meaning and Measure of Social Value in the Market. New York, NY: Cambridge University Press.

Beckert, Jens, and Patrik Aspers. 2011. "Value in Markets" In The Worth of Goods: Valuation \& Pricing in the Economy, edited by Jens Beckert and Patrik Aspers, 3-40. Oxford: Oxford University Press.

Bessy, Christian, and Pierre-Marie Chauvin. 2013. "The Power of Market Intermediaries: From Information to Valuation Processes." Valuation Studies 1 (1): 83-117.

Beunza, Daniel, and Raghu Garud. 2007. "Calculators, Lemmings or FrameMakers? The Intermediary Role of Securities Analysts. " The Sociological Review 55 (s2): 13-39.

Beunza, Daniel, and David Stark. 2005. "How to Recognize Opportunities: Heterarchical Search in a Trading Room." In The Sociology of Financial Markets, edited by Karin Knorr Cetina and Alex Preda, 84-101. New York, NY: Oxford University Press.

B-Lab. 2011. "GIIRS Rating \& Analytics for Impact Investing: Assessment 101."

Boltanski, Luc and Laurent Thévenot. 2006. On Justification: Economies of Worth. Princeton, NJ: Princeton University Press.

Bouri, Amit. 2011. "How Standards Emerge: The Role of Investor Leadership in Realizing the Potential of IRIS." Innovations Journal 6 (3): 117-31.

Brandenburg, Margot. 2010. "Making the Case for Social Metrics and Impact Investing." Development Investment Review 6 (1): 47-9.

- 2012. "Impact Investing's Three Measurement Tools." Stanford Social Innovation Review, 3 October.

Brandenburg, Margot, and Sarah Gelfand. 2009. "Impact Reporting and Investment Standards-Comment Now!" Next Billion, 2 November.

Bugg-Levine, Anthony, and Jed Emerson. 2011. Impact Investing: Transforming How We Make Money while Making a Difference. San Francisco, CA: Jossey-Bass.

Bugg-Levine, Antony, Bruce Kogut, and Nalin Kulatilaka. 2012. "A New Approach to Funding Social Enterprises." Harvard Business Review 90 (1/2): 118-23.

Çaliskan, Koray, and Michel Callon. 2010. "Economization, Part 2: A Research Programme for the Study of Markets." Economy and Society 39 (1): $1-32$.

Callon, Michel. 1998. "The Embeddedness of Economic Markets in Economics." In The Laws of the Markets, edited by Michel Callon, 1-57. Oxford: Blackwell.

- 2008. "Elaborating the Notion of Performativity." Le Libellio d'Aegis 5 (1): 18-29. 
- 2009. "Civilizing Markets: Carbon Trading between In Vitro and In Vivo Experiments." Accounting, Organizations and Society 34 (3): 53548.

Callon, Michel, and Fabian Muniesa. 2005. "Peripheral Vision: Economic Markets as Calculative Collective Devices.” Organization Studies 26 (8): 1229-50.

Callon, Michel, Cécile Méadel, and Vololona Rabeharisoa. 2002. "The Economy of Qualities.” Economy and Society 31 (2): 194-217.

Carruthers, Bruce G. 2013. "From Uncertainty toward Risk: The Case of Credit Ratings." Socio-Economic Review 11 (3): 525-51.

Chang, Susan Arterian. 2014. "Intro to Impact Investing." http:// capitalinstitute.org/braintrust/intro-impact-investing/, accessed 2 February 2015.

Cooper, Christine, Cameron Graham, and Darlene Himick. 2014. "Social Impact Bonds: Can Private Finance Rescue Public Programmes?" Working Paper, http://criticalperspectivesonaccounting.com/wp-content/ uploads/2014/07/paper-cpa-204.pdf, accessed 15 March 2015.

Cueto, Marcos (ed.). 1994. Missionaries of Science: The Rockefeller Foundation and Latin America. Indianapolis, IN: Indiana University Press.

De Goede, Marieke. 2005. Virtue, Fortune, and Faith: A Geneaology Of Finance. Minneapolis, MN: University of Minnesota Press.

Desrosières, Alain. 2001. "How 'Real' Are Statistics? Four Possible Attitudes." Social Research 68: 339-55.

Dewey, John. 1939. "Theory of Valuation." International Encyclopedia of Unified Science 2 (4): 1-67.

DiMaggio, Paul. 1994. "Culture and Economy." In The Handbook of Economic Sociology, edited by Neil Smelser and Richard Swedberg, 84101. New York, NY: Princeton University Press.

Doganova, Liliana, and Peter Karnøe. 2015. "Clean and Profitable: Entangling Valuations in Environmental Entrepreneurship." In Moments of Valuation: Exploring Sites of Dissonance, edited by Ariane Berthoin Antal, Michael Hutter, and David Stark, 229-48. New York, NY: Oxford University Press.

Eisenhardt, Kathleen M., and Melissa E. Graebner. 2007. "Theory Building from Cases: Opportunities and Challenges.” Academy of Management Journal 50 (1): 25-32.

Espeland, Wendy Nelson, and Michael Sauder. 2007. "Rankings and Reactivity: How Public Measures Recreate Social Worlds.” American Journal of Sociology 113 (1): 1-40.

Espeland, Wendy Nelson, and Mitchell L. Stevens. 1998. "Commensuration as a Social Process." Annual Review of Sociology 24: 313-43.

-. 2008. "A Sociology of Quantification." European Journal of Sociology 49 (03): 401-36. 
Fligstein, Neil. 2001. The Architecture of Markets: An Economic Sociology of Twenty-first-century Capitalist Societies. Princeton, NJ: Princeton University Press.

Fourcade, Marion. 2011. "Cents and Sensibility: Economic Valuation and the Nature of 'Nature.'” American Journal of Sociology 116 (6): 1721-77.

Garcia-Parpet, Marie-France. 2007. "The Social Construction of a Perfect Market: The Strawberry Auction at Fontaines-en-Sologne." In Do Economists Make Markets? On the Performativity of Economics, edited by Donald MacKenzie, Fabian Muniesa, and Lucia Siu, 20-53. Princeton, NJ: Princeton University Press.

Garud, Raghu. 2008. "Conferences as Venues for the Configuration of Emerging Organizational Fields: The Case of Cochlear Implants.” Journal of Management Studies 45 (6): 1061-88.

Geiger, Susi, Debbie Harrison, Hans Kjellberg, and Alexandre Mallard (eds). 2014. Concerned Markets: Economic Ordering for Multiple Values. London: Edward Elgar.

Global Impact Investing Network (GIIN). "About Impact Investing.” http:// www.thegiin.org/cgi-bin/iowa/resources/about/index.html, accessed 12 January 2015.

Global Impact Investing Reporting System (GIIRS). 2010. "Driving Capital beyond SRI to Impact." http://giirs.org/assets/pdf/GIIRSSample_Rating2010_Complete.pdf, accessed 21 January 2015.

- 2011. "Impact Investing: Challenges and Opportunities to Scale." https://www.bcorporation.net/sites/all/themes/adaptivetheme/bcorp/pdfs/ GIIRS_2011-Progress-Report.pdf, accessed 27 January 2015.

_. "Approach to Impact Investment." http:/giirs.nonprofitsoapbox.com/ about-giirs/how-giirs-works/162, accessed 1 January 2015.

Godeke, Steven and Raúl Pomares. 2009. "Solutions for Impact Investors: From Strategy to Implementation." New York, NY: Rockefeller Philanthropy Advisors.

Granovetter, Mark. 1985. "Economic Action and Social Structure: The Problem of Embeddedness." American Journal of Sociology 91 (3): 481510.

Hagerman, Lisa A. and Janneke Ratcliffe. 2009. "Increasing Access to Capital: Could Better Measurement of Social and Environmental Outcomes Entice More Institutional Investment Capital into Underserved Communities?" Community Development Investment Review 6 (1): 4364.

Hall, Matthew, Yuval Millo, and Emily Barman. 2015. "Who and What Really Counts? Accounting For Social Value and Its Relation To Stakeholder Prioritization.” Journal of Management Studies, http:// onlinelibrary.wiley.com/doi/10.1111/joms.12146/abstract, accessed 13 August 2015.

Hayat, Usman. 2013. "Impact Investing: How Do You Measure Social and Environmental Impact?” Enterprising Investor, 23 September. 
Healy, Kieran. 2006. Last Best Gifts: Altruism and the Market For Human Blood and Organs. Chicago, IL: University of Chicago Press.

Helgesson, Claes-Fredrik, and Hans Kjellberg. 2013. "Introduction: Values and Valuations in Market Practice." Journal of Cultural Economy 6 (4): 361-9.

Helgesson, Claes-Fredrik, and Fabian Muniesa. 2013. "For What It's Worth: An Introduction to Valuation Studies." Valuation Studies 1 (1): 1-10.

Huault, Isabelle, and Hélène Rainelli-Weiss. 2011. "A Market for Weather Risk? Conflicting Metrics, Attempts at Compromise and Limits to Commensuration." Organization Studies 32 (10): 1395-1419.

Impact Report Investment Standards (IRIS). 2011. "IRIS Creates a Common Language for Reporting Social and Environmental Performance.” http:// www.siaassociation.org/wp-content/uploads/2012/05/IRISOverview-2010.pdf, accessed 3 January 2015.

Jackson, Edward T. 2013. "Interrogating the Theory of Change: Evaluating Impact Investing Where it Matters Most." Journal of Sustainable Finance \& Investment 3 (2): 95-110.

J.P. Morgan. 2010. Impact Investments: An Emerging Asset Class. New York, NY: J.P. Morgan.

Karpik, Lucien. 2010. Valuing the Unique: The Economics of Singularities. Princeton, NJ: Princeton University Press.

King, Brayden G. and Nicholas A. Pearce. 2010. "The Contentiousness of Markets: Politics, Social Movements, and Institutional Change in Markets." Annual Review of Sociology 36: 249-67.

Kjellberg, Hans and Alexandre Mallard et al. 2013. "Valuation Studies? Our Collective Two Cents." Valuation Studies 1 (1): 11-30.

Kopytoff, Igor. 1986. "The Cultural Biography of Things: Commoditization as Process." In The Social Life of Things: Commodities in Cultural Perspective, edited by Arjun Appadurai, 64-91. Cambridge: Cambridge University Press.

Kozlowski, Lori. 2012. "Impact Investing: The Power of Two Bottom Lines." 10 October. http://www.forbes.com/sites/lorikozlowski/2012/10/02/ impact-investing-the-power-of-two-bottom-lines/, accessed 13 April 2013.

Krippner, Greta. 2005. "The Financialization of the American Economy." Socio-Economic Review 3 (2): 173-208.

Krogh, Matt. 2009. "Channeling Investment for Impact." https:// www.bcorporation.net/sites/all/themes/adaptivetheme/bcorp/pdfs/ 2009AP-Channeling-Impact.pdf, accessed 2 April 2015.

Lamont, Michele. 2012. "Toward a Comparative Sociology of Valuation and Evaluation." Annual Review of Sociology 38: 1-21.

Lane, Marc J. 2015. The Mission-Driven Venture: Business Solutions to the World's Most Vexing Problems. New York, NY: Wiley.

McFall, Liz. 2014. Devising Consumption: Cultural Economies of Insurance, Credit and Spending. London: Routledge. 
MacKenzie, Donald. 2009. "Making Things the Same: Gases, Emission Rights and the Politics of Carbon Markets." Accounting, Organizations and Society 34 (3): 440-55.

MacKenzie, Donald, and Yuval Millo. 2003. "Negotiating a Market, Performing Theory: The Historical Sociology of a Financial Derivatives Exchange." American Journal of Sociology 109 (1): 107-45.

Marx, Karl. 2011. Capital, Vol. 2: A Critique of Political Economy. Mineola, TX: Dover.

Monitor Institute. 2009. Investing for Social and Environmental Impact. New York, NY: Monitor Institute.

Moor, Liz, and Celia Lury. 2011. "Making and Measuring Value." Journal of Cultural Economy 4 (4): 439-54.

Muniesa, Fabian. 2012. "A Flank Movement in the Understanding of Valuation." In Measure and Value, edited by Lisa Adkins and Celia Lury, 24-38. Oxford: Wiley-Blackwell.

Muniesa, Fabian, and Michel Callon. 2007. "Economic Experiments and the Construction of Markets." In Do Economists Make Markets? On The Performativity of Economics, edited by Donald MacKenzie, Fabian Muniesa, and Lucia Siu, 163-89. Princeton, NJ: Princeton University Press.

Muniesa, Fabian, Yuval Millo, and Michel Callon. 2007. "An Introduction to Market Devices." In Market Devices, edited by Michel Callon, Yuval Millo, and Fabian Muniesa, 1-12. Oxford: Blackwell.

O’Rourke, Dara. 2005. "Market Movements: Nongovernmental Organization Strategies to Influence Global Production and Consumption." Journal of Industrial Ecology 9: 115-28.

Ortiz, Horacio. 2013. "Financial Value: Economic, Moral, Political, Global." HAU: Journal of Ethnographic Theory 3: 64-79.

Ortiz, Horacio. 2014. "The Limits of Financial Imagination: Free Investors, Efficient Markets, and Crisis." American Anthropologist 116: 38-50.

Palandjian, Tracy Pun. 2010. Investing for Impact: Case Studies across Asset Classes. London and Boston, MA: Bridges Ventures and the Parthenon Group.

Power, Michael. 2007. Organized Uncertainty: Designing a World of Risk Management. New York, NY: Oxford University Press.

Preda, Alex. 2006. "Socio-Technical Agency in Financial Markets: The Case of the Stock Ticker." Social Studies of Science 36: 753-82.

Pressner, Brad. 2009. "Social Capital Markets 09: The New Money Spectrum." Next Billion, 16 September.

Reinecke, Juliane. 2010. "Beyond a Subjective Theory of Value and towards a 'Fair Price': An Organizational Perspective on Fairtrade Minimum Price Setting." Organization 17: 563-81.

Rockefeller Foundation. 1999. 1999 Annual Report. New York, NY: Rockefeller Foundation. 
Saltuk, Yasemine, Ali El Idrissi, Amit Bouri, Abhilash Mudaliar, Hannah Schiff, J.P. Morgan, and GIIN. 2015. Eyes on the Horizon: The Impact Investor Survey. New York, NY: J.P. Morgan.

Shamir, Ronin. 2008. "The Age of Responsibilization: On Market-Embedded Morality." Economy and Society 37: 1-19.

Simon, John, and Julia Barmeier. 2011. More than Money: Impact Investing for Development. Washington, DC: Center for Global Development.

Smith, Charles W. 2007. "Markets as Definitional Mechanisms. A Robust Alternative Sociological Paradigm.” Canadian Journal of Sociology 32: 139.

Stabile, Tom. 2010. "Architects of a 'Social Investment Data Engine." Financial Times 11 April. http://www.ft.com/cms/s/0/e297b7de-440b -11df-9235-00144feab49a.html\#axzz3i8hFFhC9, accessed 11 April 2015.

Stark, David. 2011. The Sense of Dissonance. Princeton, NJ: Princeton University Press.

Strandvad, Sara Malou. 2014. "Contingencies of Value: Devices and Conventions at a Design School Admission Test." Valuation Studies 2 (2): 119-51.

Styhre, Alexander. 2013. "The Economic Valuation and Commensuration of Cultural Resources: Financing and Monitoring the Swedish Culture Sector." Valuation Studies 1 (1): 51-81.

Thornley, Ben and Colby Daily. 2009. "Building Scale in Community Impact Investing through Nonfinancial Performance Measurement.” Community Development Investment Review 6 (1): 1-46.

Timmermans, Stefan, and Iddo Tavory. 2012. "Theory Construction in Qualitative Research from Grounded Theory to Abductive Analysis." Sociological Theory 30: 167-86.

Trompette, Pascale. 2013. "The Politics of Value in French Funeral Arrangements: Three Types of Moral Calculation." Journal of Cultural Economy 6: 370-385.

Vargha, Zsuzsanna. 2011. "From Long-term Savings to Instant Mortgages: Financial Demonstration and the Role of Interaction in Markets." Organization 18 (2): 215-35.

Vatin, François. 2013. "Valuation as Evaluating and Valorizing." Valuation Studies 1 (1): 31-50.

Velthius, Olav. 2005. Talking Prices: Symbolic Meanings of Prices in the Market for Contemporary Art. Princeton, NJ: Princeton University Press.

White, Harrison C. 1981. "Where Do Markets Come from?" Advances in Strategic Management 17 (2): 323-50.

Yenkey, Christopher. 2011. "Selling Value in Kenya's Nairobi Stock Exchange." In The Worth of Goods: Valuation and Pricing in the Economy, edited by Jens Beckert and Patrick Aspers, 247-71. New York, NY: Oxford University Press.

Young, Joni J. 2006. "Making up Users." Accounting, Organizations and Society 31 (6): 579-600. 


\section{Valuation Studies}

Zelizer, Viviana. 1983. Morals and Markets: The Development of Life Insurance in the United States. New York, NY: Transaction.

- 2005. The Purchase of Intimacy. Princeton, NJ: Princeton University Press.

Zuckerman, Ezra W. 1999. "The Categorical Imperative: Securities Analysts and the Illegitimacy Discount.” American Journal of Sociology 104 (5): 1398-438.

Emily Barman is an Associate Professor of sociology at Boston University. Her research interests include economic sociology, organizational theory, nonprofit studies, and the marketization of social impact. Her publications include Contesting Communities: The Transformation of Workplace Charity (Stanford University Press 2006) and articles in American Journal of Sociology, Social Science History, and Voluntas, among others. Her next book, Caring Capitalism: The Meaning and Measure of Social Value in the Market, is planned for publication in 2016 with Cambridge University Press. 